\title{
SoTe-tieto ekosysteemissä: MORFEUS-näkymät asiakaslähtöisen yhteistyön ja palveluohjauksen työkaluina
}

Tarja Kantola, FT, yliopettaja; Päivi Pöyry-Lassila, FT, yliopettaja; Tarja Meristö, KTT, yliopettaja

Laurea-ammattikorkeakoulu

Tarja Kantola, FT, yliopettaja, Laurea-ammattikorkeakoulu, Porvoo Campus, Taidetehtaankatu 1, 06100 Porvoo, FINLAND. Sähköposti: tarja.kantola@laurea.fi

\section{Tiivistelmä}

Sote-uudistus haastaa alan toimijat julkisella, yksityisellä ja kolmannella sektorilla kehittämään yhteistyötään asiakkaan parhaaksi. Monitoimijaisessa verkostossa tarvitaan paitsi kokonaiskuvaa palveluekosysteemin toimijoista rooleineen myös saumatonta tiedonkulkua toimijoiden välillä. Kehitettävien tietojärjestelmien tulee olla yhteentoimivia, mutta myös erityisiä tarpeita omaavien asiakkaiden palvelutarpeet täytyy huomioida. Vuosina 2015-2017 toteutettavassa MORFEUS-hankkeessa on kehitetty ja testattu kansallista palveluväylää hyödyntävä näkymäprototyyppi, joka mahdollistaa tietojen koostamisen eri toimijoiden tietovarannoista kolmeen eri käyttäjänäkymään: asiakkaan, sote-ammattilaisen sekä päätöksentekijän. Näkymät mahdollistavat erityistä tukea ja erityisen runsaasti erilaisia sote-palveluita tarvitsevien ns. VIP-asiakkaiden palvelupaletin koostamisen ja palveluohjauksen. Käyttäjätestausten pohjalta voidaan todeta, että prototyypin idea toimii; se auttaa koostamaan tietoa eri lähteistä ja mu odostamaan kokonaiskuvan asiakkaan tilanteesta sekä asiakkaalle itselleen että sote-ammattilaiselle, mistä on erityistä hyötyä palveluohjaajalle. Käyttäjätestauksen pohjalta voidaan todeta, että näkymäprototyypin jatkokehitystä täytyy tehdä vielä fokusoiden erityisesti testaukseen käyttäjäasiakkaiden kanssa, tiedon rakenteiseen kirjaamiseen ammattilaisten näkymässä sekä tiedon esittämiseen visuaalisessa muodossa kaikissa näkymissä. Erityisesti asiakkaan näkymässä visuaalisuudella tavoitellaan asiakkaan voimaantumista, motivoitumista sekä houkuttelevuutta ja ei-leimaavuutta.

Avainsanat: tietojärjestelmät, palveluväylä, sote-tieto, ekosysteemi 


\section{Abstract}

Social and healthcare reform challenges the actors in the public, private and third sectors to develop their cooperation for the customer's best. The multi-actor network needs not only the overall picture of the services and of their roles in the ecosystem, but also the fluent information flow between the actors in it. The developed information systems must be interoperable, but also the customers' service needs must be taken into accounts. In the MORFEUS project (2015-2017) we have developed and tested a view prototype utilizing the idea of a state portal website enabling to combine and use various information resources. In the prototype we have developed by now three different views for three different users: the customer, the social and health care professional (a service advisor/a case manager) as well as the decision-maker. The views help to support a so called VIP-customer, who needs a special assistance or especially much support in his/her situation and to perceive the entire service packet in hand. Based on the user testing, it can be said that the idea to the prototype works. It helps to combine information from different sources and to get an overall picture of the situation of the customer to herself/himself and to the professional. Still, more testing is needed with e.g. customer families using child protection services as well as taking care of the ideas of structural documenting and of visualizing the system for promoting the empowerment and motivation of a customer as well as minimizing a possible stigma.

Keywords: information systems, a state portal website, social and health knowledge, ecosystem

\section{Johdanto}

Sote-uudistus Suomessa haastaa toimijat niin yksityiseltä, julkiselta kuin kolmanneltakin sektorilta, mutta myös kansalaiset, jotta tavoiteltu visio muuttuu todeksi. Monitoimijaisessa yhteistyöverkostossa tarvitaan kokonaiskuvaa ekosysteemin eri toimijoista rooleineen, ja tiedonkulun toimijalta toiselle on oltava saumatonta ja reaaliaikaista. Kansalaisen on pystyttävä hahmottamaan oman hyvinvointinsa tilaa ja kehitystä ammattilaisten rinnalla, ja ennakoivan otteen mukaisesti jokaisella pitää olla käsitys niistä muutosta ennakoivista vihjeistä, joiden perusteella voidaan tarvittaessa puuttua tilanteeseen ja tehdä korjausliikkeitä ennen kuin on myöhäistä. [1,2] Kansalaisen valinnanvapaus osana soteuudistusta vaatii osaamista ja tietoa tarpeista, mutta myös tarjottavista palveluista. On kehitettävä tietojärjestelmiä ja sovelluksia suuntaan, jossa oman luukun periaatteella, mobiilistikin on mahdollista toimia, kuten nyt esittelyssä olevassa MORFEUS-hankkeessa, mutta myös aiemmin toteutetussa Omahyvinvointi hankkeessa, jossa kehitettiin henkilökohtainen hyvinvointinavigaattori kansalaisen pärjäämiseksi muuttuvassa maailmassa. [3-5]
Yhteentoimivien tietojärjestelmien kehittäminen ja käyttöönotto ovat keskeisiä edellytyksiä soteuudistuksen tavoitteiden toteuttamiselle. Yhteentoimivuus edellyttää muun muassa tietojen standardimuotoista esittämistä, koodistoja ja tietojen siirtymistä eri järjestelmien välillä. Tietojärjestelmien kehittämisessä taas huomio olisi suunnattava järjestelmien käyttäjäasiakkaisiin, ei ainoastaan sote-ammattilaisiin vaan erityisesti kansalaisiin. [6] Sote-tietojärjestelmien kehittämistä ohjaa muun muassa kansallinen palveluarkkitehtuuriohjelma (KaPA), jonka tavoitteena on luoda maahamme mahdollisimman kattava ja yhteentoimiva digitaalisten palveluiden infrastruktuuri. Olennainen elementti KaPA:ssa on Palveluväylä, tiedonvälityskerros, joka mahdollistaa ja määrittää tiedonvälityksen siihen liittyneiden eri tietojärjestelmien välillä. Palveluväylä on tiedonvälityspalvelu, jonka avulla siihen liittyneet eri toimijat (ml. julkinen hallinto, yritykset) voivat hyödyntää muita Palveluväylään liittyneitä palveluita ja tietovarantoja. Palveluväylän yhtenä tavoitteena on mahdollistaa uudenlaisia toiminta- ja palvelumalleja. [7] Palveluväylän lisäksi on kehitetty Palvelunäkymät, joista kansalainen voi muun muassa hakea julkisen hallinnon palvelutietoja, nähdä eri palveluista ja rekistereistä kootut omat tietonsa sekä käyttää eri palveluita yhdellä kirjautumisella. [8] 
Edellä kuvatut kansalliset tietojärjestelmähankkeet ovat suuri edistysaskel digitaalisten palveluiden kehittämisessä, ja mahdollistavat monia uudenlaisia palveluita ja tiedonkulun malleja. Palvelut on kuitenkin kehitetty ns. normaalikäyttäjille, jotka pystyvät omatoimisesti koostamaan omat palvelupalettinsa ilman ulkopuolista tukea. Erityisiä tuen tarpeita omaavien käyttäjien näkökulma jää kuitenkin vielä pimentoon. MORFEUS ${ }^{1}$ -hankkeessa toteutetussa tietojärjestelmäprototyypissä olemme huomioineet sekä KaPAn että Palveluväylän ja Palvelunäkymien kehitystyön, ja olemme rakentaneet prototyypin erityisesti ns. VIP-asiakasryhmälle. Tässä yhteydessä VIP-asiakkailla tarkoitamme erityistä tukea ja erityisen paljon erilaisia sote-palveluita tarvitsevia asiakkaita, kuten lastensuojelun asiakasperheitä tai päihde- ja mielenterveyspalveluiden asiakkaita, joilla on tyypillisesti paletissaan lukuisia sote-palveluita. Esimerkiksi Sitran tutkimuksen mukaan asiakkaista eniten palveluita tarvitsevan 10 prosentin sote-palvelut aiheuttavat 74 prosenttia kustannuksista. [9] Palveluiden tarpeen laajuus ja omien voimavarojen rajallisuus sekä palveluntuottajien moninaisuus johtavat erityiseen palveluohjauksen tarpeeseen. Palveluohjaaja on sotealan ammattilainen, joka on tiiviissä kontaktissa asiakkaan kanssa ja integroi palvelupaletin asiakkaan kulloistenkin tarpeiden mukaiseksi.

MORFEUS-hanke (1.1.2015-30.6.2017) on Laureaammattikorkeakoulun ja Aalto-yliopiston yhteinen monitieteinen tutkimus- ja kehittämishanke. MORFEUShankkeessa tutkitaan kehittävän toimintatutkimuksen otteella hyvinvointipalvelujen monitoimijaisia ekosysteemejä ja kehitetään niitä palvelumuotoilun, tietomallintamisen ja tulevaisuudentutkimuksen lähestymistavoilla huomioiden myös lainsäädäntö ja sopimuskäytännöt. Tarkastelun kohteena ovat ekosysteemin toimijat eli hyvinvointialan yritykset, julkisen ja kolmannen sektorin organisaatiot sekä toimijoiden väliset suhteet. Myös asiakkaat perheineen ovat osa tätä ekosysteemiä, ja heitä ovat hankkeessa edustaneet

\footnotetext{
${ }^{1}$ MORFEUS -akronyymi muodostuu sanoista Mallinnettu informaatio, O- sallistavat työtavat, Rakentuva tulevaisuus, Fasilitoitu yhteistyö ja Ennnakoiva innovointi Uuudistuvassa Sosiaali- ja terveydenhuollossa.
}

kokemusasiantuntijat. Tutkimus- ja kehittämistyö on fokusoitu erityisesti päihde-, mielenterveys- ja lastensuojelupalveluiden kokonaisuuksiin. Artikkelissa tarkasteltu prototyypin testaus on fokusoitunut lastensuojelupalveluihin. [10]

Hankkeen lähtökohta on asiakaslähtöisyys, ja palveluekosysteemiä tukevaa tietomallinnusta on tutkittu ja kehitetty hankkeessa konstruoidun todellisista caseistä aineksia saaneen case-esimerkkiperheen tarvitseman palvelukokonaisuuden avulla. Hankkeen tutkimus- ja kehittämistyö on toteutettu tiiviinä yhteistyönä hankkeen Case-kumppanien HUSin ja Porvoon kaupungin kanssa. Porvoon lastensuojelun ekosysteemin toimijat ovat osallistuneet aktiivisesti toiminnalliseen ja osallistavaan Tulevaisuusskenaario -työskentelyyn, jossa on hahmotettu yhteisesti lastensuojelun ekosysteemin toimijoita, case-asiakasperheen eri perheenjäsenten palvelupolkuja ja tiedonkulun pullonkauloja ja vahvuuksia niissä sekä luotu yhdessä erilaisia tulevaisuuden skenaarioita lapsiperheiden hyvinvoinnin tukemiseksi. Tulevaisuusskenaario -työskentelyssä on ollut mukana myös kokemusasiantuntijoita. Artikkelissa tarkasteltavan prototyypin testauksessa Tulevaisuusskenaario työskentelyyn osallistuneilla toimijoilla on ollut keskeinen rooli. Koko MORFEUS-hankkeen hankekumppanit edustavat kattavasti eri sosiaali- ja terveysalan palveluekosysteemin osapuolia Uudeltamaalta kuntasektorilta, hyvinvointipalveluiden tuottajista sekä digitaalisten työvälineiden ja konsulttipalveluiden tuottajista, ja hankkeessa tuotetun prototyypin testaus ja arviointi heidän kanssaan jatkuu edelleen loppukevään 2017 aikana. [10]

Hankkeessa on kehitetty tietomallinnuksen kehikkoa, johon kaikki palvelun hankkimiseen ja tuottamiseen tarvittava tieto voitaisiin liittää. Lähtökohtana on ollut idea siitä, että tulevaisuusorientaatioon pohjaava prototyyppi toimii ympäristössä, jossa Palveluväylä on realisoitunut. Tietomallinnus selkeyttää toimijoiden väliset roolit, suhteet ja tietotarpeet, jotta tulevaisuudessa voidaan kehittää, tuottaa ja hankkia uudenlaisia palveluja kustannustehokkaammin ja asiakaslähtöisemmin. Hankkeen tulosten pohjalta on mahdollista kehittää uudenlaisia digitaalisia työvälineitä palveluekosysteemin toiminnan tueksi. 
Tässä artikkelissa esitellään MORFEUS-hankkeessa kehitetty ja testattu prototyyppi (Proto) sekä esitetään johtopäätöksiä ja ideoita sote-tietojärjestelmien jatkokehittämiseen MORFEUS-hankkeen tulosten pohjalta. Tutkimuskysymyksemme on: Millainen prototyyppi ja miten on kehitetty MORFEUS-hankkeessa tukemaan paljon ja erityistä tukea tarvitsevan sote-asiakkaan ja sote-ammattilaisen virtuaalista vuorovaikutusta? Asiakkaan ja sote-ammattilaisen uudenlaista työskentelytapaa peilataan MORFEUS-prototyypin avulla.

\section{MORFEUS-prototyyppi}

Kansalliset tietojärjestelmähankkeet ovat suuri edistysaskel digitaalisten sote-palveluiden kehittämisessä, ja mahdollistavat monia uudenlaisia palveluita ja tiedonkulun malleja. MORFEUS-hankkeessa kehitetyssä ja testatussa näkymäprototyypissä olemme huomioineet sekä KaPAn että Palveluväylän ja Palvelunäkymien kehitystyön, ja olemme rakentaneet prototyypin erityisesti ns. VIP-asiakasryhmälle. Tässä yhteydessä VIPasiakkailla tarkoitamme erityistä tukea ja erityisen paljon erilaisia sote-palveluita tarvitsevia asiakkaita, kuten lastensuojelun asiakasperheitä tai päihde- ja mielenterveyspalveluiden asiakkaita, joilla on erityinen palveluohjauksen tarve.

MORFEUS-hankkeessa tuotetun tietojärjestelmäprototyypin avulla voidaan tuottaa mahdollisimman kattava moniammatillinen kokonaiskuva sote-asiakkaan tilanteesta ja yhteinen suunnitelma asiakkaan tukemiseksi Prototyyppi yhdistää asiakkaan tiedot eri tietojärjestelmistä ja -rekistereistä Palveluväylän avulla. MORFEUSnäkymiin kerätään tiedot mm. Kanta-palvelusta [11], tulevasta sosiaalihuollon Kanta-palvelusta [12] ja muista julkisen, yksityisen ja kolmannen sektorin sotepalveluntuottajien tietojärjestelmistä. Tämän artikkelin kirjoittamisen kanssa rinnan on edennyt myös MORFEUS-hankkeen ja muiden kansallisten tietojärjestelmähankkeiden, kuten esim. APOTTI-hanke suhteutus ja vertailu toisiinsa. MORFEUS-näkymät mahdollistavat paitsi asiakkaan/kansalaisen tietojen kokoamisen yhteen näkymään, myös asiakkaan palveluohjauksen sekä tiedonvälityksen ja yhteydenpidon eri palveluntarjoajien välillä.

MORFEUS-näkymät mahdollistavat asiakkaan kokonaistilanteen ja tarpeiden arvioimisen kokonaisvaltaisesti, mistä on hyötyä jatkotyöskentelyssä muun muassa asiakkaan tarvitsemien sote-palveluiden määrittämisessä. Asiakkaan tilanteen kokonaisnäkymän avulla asiakas nousee työskentelyn keskiöön ja ammattilaisten päällekkäinen työ vähenee. Näkymän avulla niin asiakkailla itsellään kuin myös asiakkaan kanssa toimivilla tahoilla, joilla on oikeus näkymiin, tarvittaessa myös asiakkaan luvalla, on käytössään yhteinen arvio asiakkaan tilanteesta ja suunnitelma hänen palvelupaletistaan. Erityistä MORFEUS-hankkeessa luodussa prototyypissä ja näkymissä on se, että asiakas itse on aktiivisessa roolissa itseään koskevan tiedon tuottajana, ei pelkästään tiedon käyttäjänä. Asiakas voi myös halutessaan lisätä omia läheisiään toimijoiksi järjestelmään.

\section{MORFEUS-näkymäprototyypin toteutus}

Lähtökohtana prototyypin kehittämiselle on ollut visio digitaalisten palveluiden maailmasta, jossa eri toimijoiden muodostama ekosysteemi toimii ennakoivasti ja kykenee ottamaan huomioon tilannetta ja siinä tapahtuvia muutoksia ennakoivasti. Tässä yhteydessä on otettu käyttöön ammattilaisten termi huoli, huolenilmaisu, $[13,1]$ joka voi olla signaali tilanteen ja olotilan heikkenemisestä, mutta joskus tarkempi tarkastelu voi myös osoittaa huolen aiheettomaksi. Lähtökohtana prototyypin huolimittarille (Kuvio 1.) on ollut ajatus siitä, että kun kukin toimija ilmaisee tuntemansa huolen ajoissa ja että pystytään arvioimaan huolen kehitystä ajan kuluessa eri toimijoiden tahoilta. Näin huoli joko kumuloituu, jolloin kyetään ajoissa tekemään jotakin tai huoli hälvenee eikä tarvetta isommille interventioille ole. Ajatuksena huolimittarissa on ollut myös se, että huolenilmaus vakiintuessaan monitoimijaiseen käyttöön vähentää myös huolenilmauksen leimaavaa vaikutusta. Vastapainoksi huolenilmaisulle on prototyyppiä luotaessa pohdittu myös voimaantumiseen liittyvien havaintojen kirjaamista ja voimaantumisen muutoksen visualisointia. 


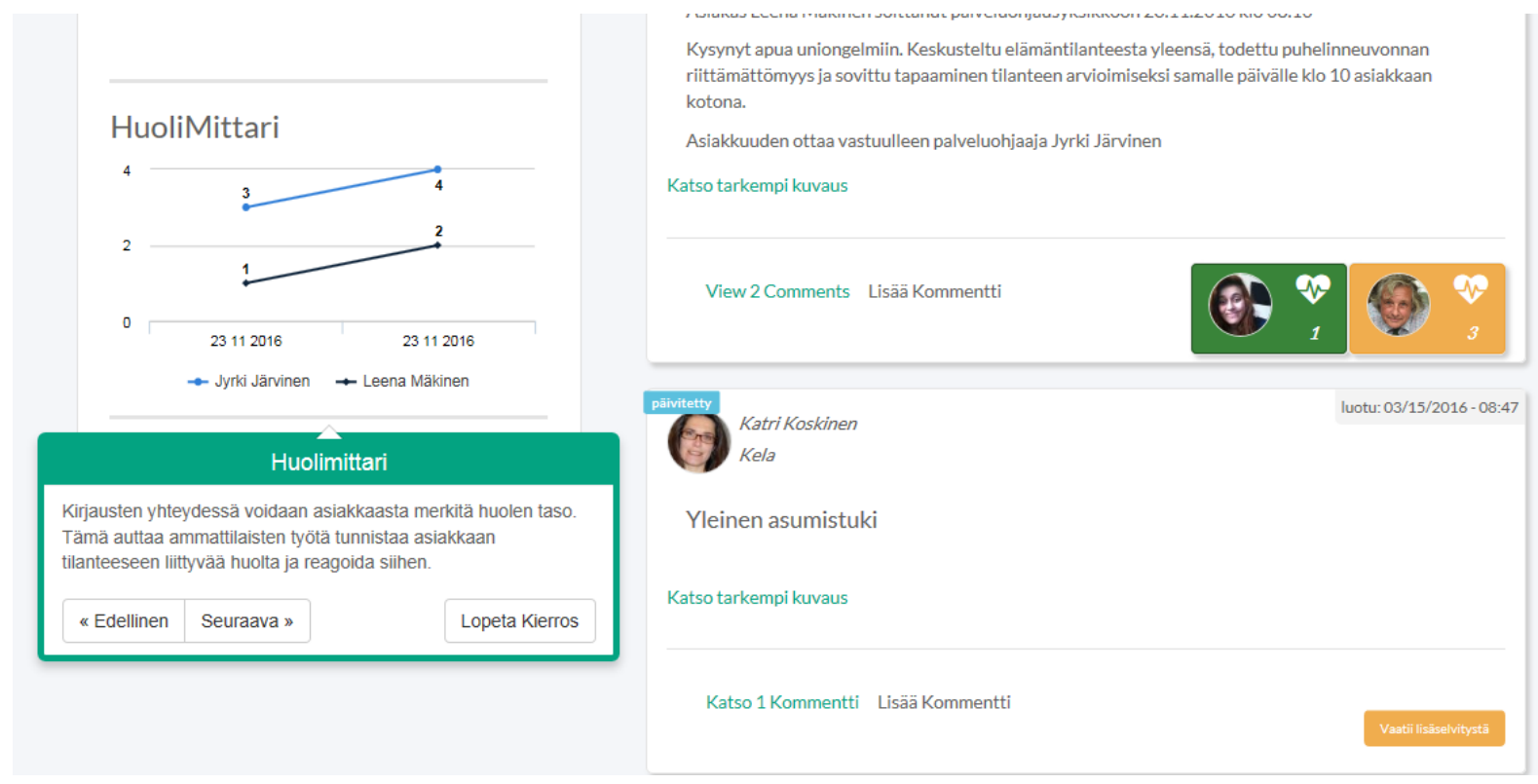

Kuvio 1. Huolimittari Protossa (testausten pohjalta kehitetty näkymä). Nimet artikkelin näkymäkuvioissa ovat kuvitteellisia.

Huoli voidaan nähdä heikkona signaalina, joka kertoo siitä, mitä mahdollisesti on tulossa. Sen rooli ennakoivissa sote-palveluissa on välttämätön. Ilman sitä ei ole mahdollista toimia ajoissa, ennen ongelmien kärjistymistä. Huolenilmaus kertoo asiakkaalle, että hänestä välitetään ja että myös hän itse voi toimia huolen hälventämiseksi.

Ideaaliprototyyppi sisältää näkymät kaikille ekosysteemin toimijoille, mukaan luettuna asiakas, jolloin reaaliaikainen tieto on kaikkien ulottuvilla ja vuoropuhelu on mahdollista helpostikin. Käytännössä MORFEUShankkeessa rakennettu prototyyppi on ollut tätä artikkelia kirjoitettaessa edelleen testaus- ja kehittelyvaiheessa ja se sisältää vasta kolme näkymää: yksi palvelun asiakkaalle, yksi sote-ammattilaiselle/palveluohjaajalle ja yksi päättäjälle. Reaaliaikainen kommentointimahdollisuus ja yhteydet tietokantoihin on rakennettu, ja kunkin toimijan osalta on mahdollista päivittää ja lisätä linkkejä Protoon, jotta se vastaa mahdollisimman hyvin käytännön tilannetta.

Eri näkymien tarkoituksena on koota kullekin näkymän käyttäjäryhmälle oleellista tietoa eri tietojärjestelmistä
Palveluväylää hyödyntäen. Näkymien kehittämisen johtoajatuksena on ollut integroidun ja tarpeita vastaavan palvelun mahdollistaminen asiakkaalle uudenlaisen työskentelymallin avulla, johon kuuluvat asiakkaan ja sote-ammattilaisen raja-aitojen madaltaminen ja mahdollisimman tasavertainen toimijuus ja vuoropuhelu palveluekosysteemin eri toimijoiden välillä.

Asiakkaan näkymään (Kuvio 2.) on koottu kattavat tiedot hänen saamistaan palveluista sekä kuvattu asiakkaan näkökulmasta hänen oma henkilökohtainen palveluverkostonsa, eri ammattilaisten kanssa vaihdetut viestit, ammattilaisten tekemät ja hänen itsensä tekemät kirjaukset ja muun muassa vireillä olevat hakemukset ja niiden tila (palvelut, etuudet) sekä huolimittari, johon on koottu paitsi asiakkaan oma myös eri soteammattilaisten kokemus asiakkaan tilanteen huolestuttavuudesta. 

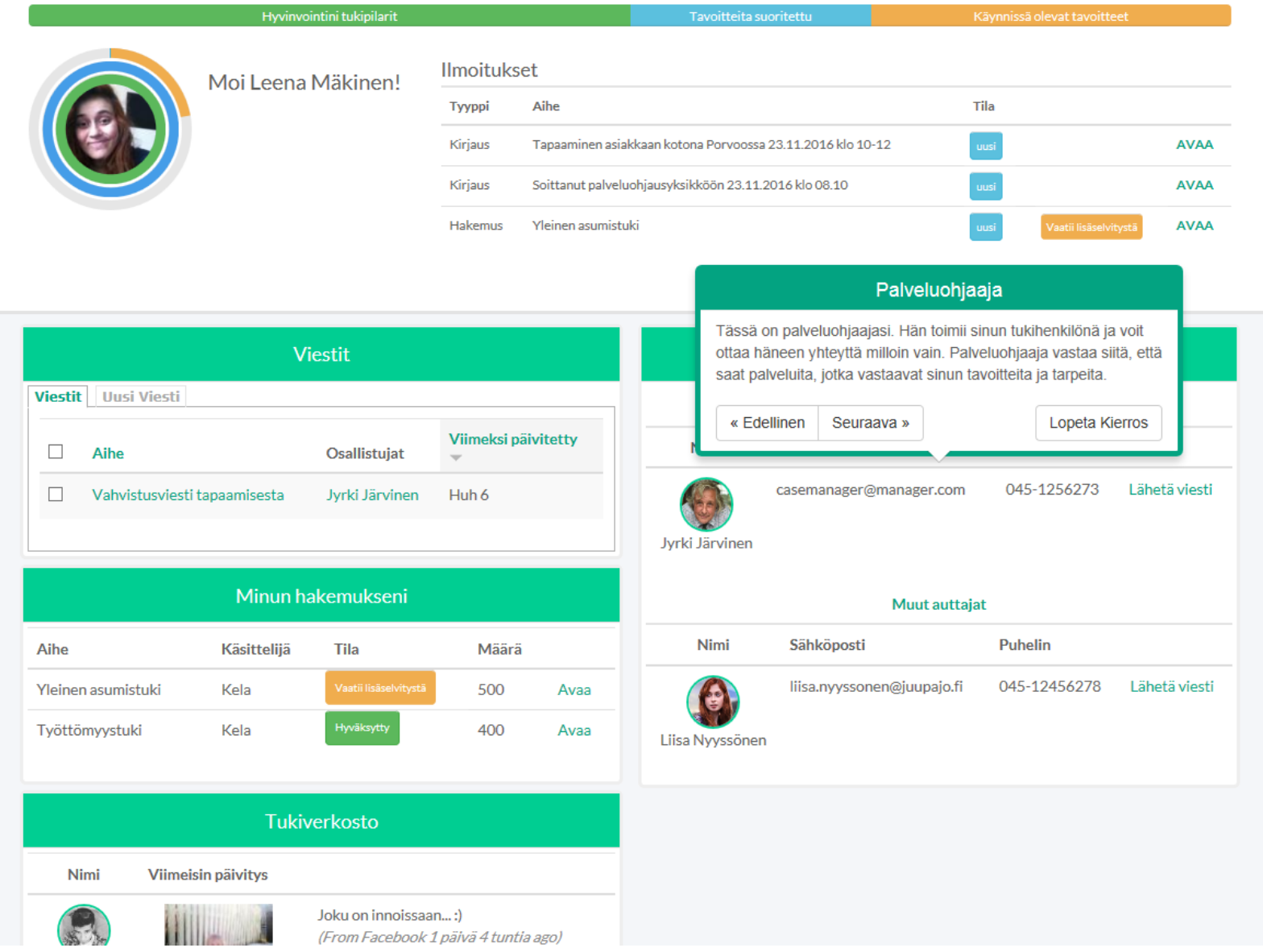

Kuvio 2. Asiakkaan näkymä Protossa (testausten pohjalta kehitetty näkymä).

Sote-ammattilaisen näkymä (Kuvio 3.) n kehitetty erityisesti palveluohjaajan [14] työkaluksi, mutta sitä voivat käyttää muutkin asiakkaan kanssa kontaktissa olevat sote-ammattilaiset. Näkymän avulla palveluohjaaja pystyy katselemaan kaikkien ohjattavien asiakkaidensa tietoja ja olemaan yhteydessä asiakkaidensa kanssa viestityökalun avulla. Näkymän avulla palveluohjaaja pystyy myös tekemään kirjaukset asiakkaistaan ja viestimään asiakkaan tilanteesta nousevaa huolta huolimittarin avulla. Näkymän avulla kaikki asiakkaan kanssa työskentelevät sote-ammattilaiset julkisella, yksityisellä ja kolmannella sektorilla saavat ajantasaiset tiedot asiakkaastaan. Näin näkymät mahdollistavat yhtenäisen palvelun tuottamisen asiakkaalle monitoimijaisen palveluekosysteemin yhteistyönä.

Päätöksentekijän näkymä on kehitetty johtaja/päätöksentekotasolle tiedolla johtamisen työkaluksi. Näkymä koostaa sote-päätöksentekijälle tietoja valitun palveluekosysteemin resurssien käytöstä, vaikuttavuudesta, asiakaspalautteesta, palvelutarpeen kehityksestä ja muusta palveluiden seurannassa ja päätöksenteossa tarvittavasta tiedosta. Näkymän tietojen avulla päätöksentekijä pystyy suunnittelemaan palvelutarjontaa ja muun muassa hankintoja proaktiivisesti. 
Leena Mäkinen

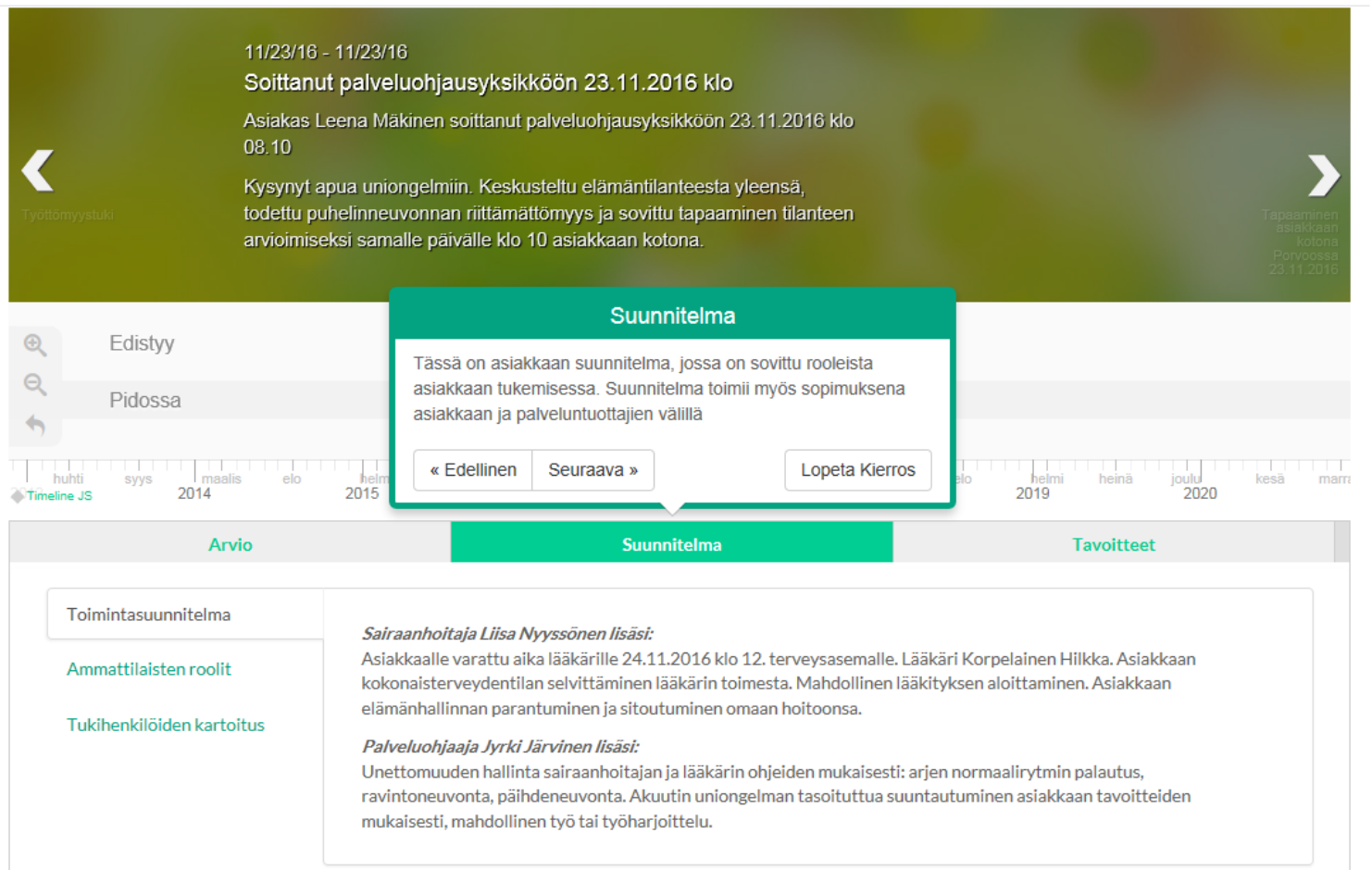

Kuvio 3. Sote-ammattilaisen näkymä Protossa (testausten pohjalta kehitetty näkymä).

\section{Näkymäprototyypin käyttäjätestaus ja sen tulokset}

MORFEUS-hankkeessa luotu prototyyppi (Proto) on kehitetty hankkeen viimeisen toimintavuoden aikana ensin konstruoidun lastensuojelun asiakasperhe-caseä hyödyntäen ja myöhemmin todellisista caseista lisää näkökohtia ammentaen. Protoa on esitelty ja saatu palautetta hankkeen Välitulosseminaarissa lokakuussa 2016, minkä jälkeen varsinaisia testaustilanteita on organisoitu eri käyttäjäryhmien roolitusten mukaisesti, jolloin Protoa on testattu asiakkaan, palveluohjaajan ja päättäjän näkökulmista. Testaajina toimivat Porvoon lastensuojelun ekosysteemin todellisten toimijoiden lisäksi Laurean MORFEUS-tiimin tutkijat ja hankkeeseen opinnäytetöiden kautta integroituneet Laurean sotealan opiskelijat Porvoosta, Leppävaarasta ja Hyvinkäältä.

Proton testauksen valmistelutyössä käytiin läpi eri näkökulmat, joita työn taustalla olevalla tietomallinnuksel- la tavoitellaan. Tutkijatiimissä hahmotettiin tavoitteeksi neljä erilaista näkökulmaa, jotka ovat voimaantuminen, varhainen puuttuminen, tiedonkulku ja kokonaiskuvan selkeyttäminen. Näiden tärkeysjärjestys voi eri toimijoilla vaihdella ja esimerkiksi asiakasnäkökulmasta keskeisiä ovat voimaantuminen ja varhainen tuen saanti, kun taas ammattilaiselle voi korostua kokonaiskuva ja tiedonkulku. Kaikki neljä näkökulmaa ovat kuitenkin läsnä kaikilla toimijoilla, kun mietitään tietomallinnuksen tavoitteita, ja näkökulmat haluttiin pitää mielessä myös Proton testauksessa, jossa ne otettiin osaksi testauksen koontilomaketta.

MORFEUS-näkymiä on testattu eri käyttäjäryhmien kanssa syksyllä 2016. Testitilanteet olivat suunniteltuja käyttäjätestauksia, joissa edettiin ennalta tuotetun käsikirjoituksen ja skenaarioiden pohjalta. Käyttäjätestaukset toteutettiin Laurea-ammattikorkeakoulussa Porvoon Campuksella sekä virtuaalisesti. Testauksia oli yhteensä kolme, ja testaajina toimivat ensiksi Laurean 
sairaanhoitaja-, terveydenhoitaja-, sosionomi- ja yamkopiskelijat yhdessä Laurean MORFEUS-tiimin kanssa sekä myöhemmin yhdessä Porvoon lastensuojelun ekosysteemin toimijoiden ja Laurean MORFEUS-tiimin kanssa. Testauksen eteneminen on kuvattu taulukossa 1.

Taulukko 1. Proton testauksen eteneminen.

\begin{tabular}{|c|c|c|c|c|c|}
\hline $\begin{array}{l}\text { Testauksen } \\
\text { ajankohta }\end{array}$ & $\begin{array}{l}\text { Testaus ja sen } \\
\text { luonne }\end{array}$ & Paikka & Testaajat & Testauksen kohde & $\begin{array}{l}\text { Havaintojen koonti } \\
\text { testauksessa }\end{array}$ \\
\hline 27.10 .2016 & $\begin{array}{l}\text { Proton opiskeli- } \\
\text { jatestaus; } \\
\text { Online-testaus; } \\
\text { Laurea }\end{array}$ & $\begin{array}{l}\text { Verkko, } \\
\text { Laurea; } \\
\text { Porvoo } \\
\text { Campus }\end{array}$ & $\begin{array}{l}\text { Laurean sote-alan } \\
\text { opiskelijat: } 4 \\
\text { Morfeus-tiimin } \\
\text { jäsenet: } 5\end{array}$ & $\begin{array}{l}\text { Tietomallinnuksen } \\
\text { idea }^{2} \\
\text { Proton asiakas- ja } \\
\text { asiantuntija- } \\
\text { näkymien testaus }\end{array}$ & $\begin{array}{l}\text { Online, paperitse } \\
\text { koonti-lomakkeelle }\end{array}$ \\
\hline $\begin{array}{l}15 .-16.11 . \\
2016\end{array}$ & $\begin{array}{l}\text { Proton virtuaa- } \\
\text { litestaus; } \\
\text { opiskelijatesta- } \\
\text { us; } \\
\text { Online-testaus; } \\
\text { Laurea }\end{array}$ & $\begin{array}{l}\text { Verkko: } \\
\text { Proton } \\
\text { online- } \\
\text { testaus }\end{array}$ & $\begin{array}{l}\text { Laurea sote-alan } \\
\text { opiskelijat: } 5 \\
\text { Morfeus-tiimin } \\
\text { jäsenet: } 3\end{array}$ & $\begin{array}{l}\text { Tietomallinnuksen } \\
\text { idea } \\
\text { Proton asiakas- ja } \\
\text { asiantuntijanäky- } \\
\text { mien testaus }\end{array}$ & $\begin{array}{l}\text { Online, sähköisesti } \\
\text { yhteiselle koonti- } \\
\text { lomakkeelle }\end{array}$ \\
\hline 23.11.2016 & $\begin{array}{l}\text { Proton online- } \\
\text { testaus; Lasten- } \\
\text { suojelun } \\
\text { ekosysteemin } \\
\text { toimijatestaus }\end{array}$ & $\begin{array}{l}\text { Verkko; } \\
\text { Proton } \\
\text { online- } \\
\text { testaus; } \\
\text { Porvoo } \\
\text { Campus }\end{array}$ & $\begin{array}{l}\text { Porvoon lastensuo- } \\
\text { jelun ekosysteemin } \\
\text { toimijat: } 3 \\
\text { Laurean sote-alan } \\
\text { opiskelijat: } 7 \\
\text { Morfeus-tiimin } \\
\text { jäsenet: } 5\end{array}$ & $\begin{array}{l}\text { Tietomallinnuksen } \\
\text { idea } \\
\text { Proton asiakas- ja } \\
\text { asiantuntijanäky- } \\
\text { mien testaus } \\
\text { Asiakkaan palvelu- } \\
\text { tarpeen arvioinnin } \\
\text { tekeminen pro- } \\
\text { tossa }\end{array}$ & $\begin{array}{l}\text { Online, sähköisesti } \\
\text { yhteiselle koonti- } \\
\text { lomakkeelle }\end{array}$ \\
\hline
\end{tabular}

\footnotetext{
${ }^{2}$ Elementit prototyypin taustalla olevassa tietomallinnuksessa: voimaantuminen, varhainen puuttuminen, tiedonkulku ja kokonaiskuvan selkeyttäminen asiakas- ja ammattilaistoimijanäkökulmista.

${ }^{3}$ Elementit näkymisen testauksessa: tekninen toimivuus ja helppolöytöisyys, toimijakytkökset, siilojen ja rajojen ylitys monitoimijaisessa yhteistyössä.
} 
Testausaineiston ja tulosten analysointi on ollut tätä artikkelia kirjoitettaessa vielä meneillään, ja Protoa on kehitetty edelleen testauksen pohjalta. Valintoja Proton edelleen kehittämiseksi on tehty paitsi testauksen myös MORFEUS-hankkeen aiempien tulosten pohjalta. Paljon keskustelua herättivät testauksessa käyttöliittymään liittyvät asiat, mutta testauksessa päästiin kiinni myös Proton taustalla vaikuttaviin ideologisiin asioihin ja niiden ilmenemiseen Protossa, kuten asiakaslähtöisyyden, tasavertaisuuden ja voimaannuttavuuden ideaan. Ne miellettiin testauksissa läpileikkaavina asioina niin Proton visuaaliseen ilmeeseen (esim. värit, visuaalisuus ja grafiikka runsaan tekstin ja dokumenttien sijaan) kuin myös sen kielellisiin valintoihin (esim. varhainen tuk varhaisen puuttumisen sijaan, huoli vs./ja voimavarat) ja toiminnalliseen rakenteeseenkin liittyvinä seikkoina (näkymien toiminnallinen selkeys, asioiden helppolöytöisyys ja vuorovaikutteisuus, kirjaamisen rakenteisuus).

\section{MORFEUS-prototyyppi}

Artikkelissa on tarkasteltu tutkimuskysymystä, millainen prototyyppi ja miten on kehitetty MORFEUShankkeessa tukemaan paljon ja erityistä tukea tarvitsevan sote-asiakkaan ja sote-ammattilaisen virtuaalista vuorovaikutusta.

Käyttäjätestauksesta kootun aineiston pohjalta voidaan todeta, että MORFEUS-näkymä -prototyypin idea toimii; se auttaa koostamaan tietoa eri lähteistä ja muodostamaan kokonaiskuvan asiakkaan tilanteesta sekä asiakkaalle itselleen että sote-ammattilaiselle. Erityistä hyötyä asiakkaan kokonaiskuvan hahmottamisesta on myös sote-palveluohjaajalle, jolloin tieto asiakkaan tilanteesta, huolesta ja palvelutarpeista on koordinoitavissa.

Näkymäprototyypin jatkokehitystä täytyy tehdä vielä fokusoiden erityisesti tiedon rakenteiseen kirjaamiseen $[15,16]$ ammattilaisten näkymässä sekä tiedon esittämiseen visuaalisessa muodossa kaikissa näkymissä. Sotepalveluiden VIP-asiakkaiden voimavarojen ollessa rajalliset, täytyy erityisesti asiakkaan näkymässä visuaalisuudella tavoitella järjestelmän käytön houkuttelevuutta, asiakkaan voimaannuttamista sekä ei leimaavuutta.
Proton jatkokehittämistyö ja -testaaminen Laureassa ovat jatkuneet laajemmalla sosionomiopiskelijoiden ryhmällä keväällä 2017 ja jatkuvat edelleen loppukeväällä 2017, kun prototyyppi julkistetaan avoimesti verkossa kokeiltavaksi ns. ProtoTourin idealla, joka johdattaa kävijän eri näkymien kautta Protoon. MORFEUS-hankkeen päätyttyä prototyypin kehittämistyön toivotaan siirtyvän käytännön toimijoille, esim. sotetietojärjestelmiä kehittävälle organisaatiolle. MORFEUShankkeessa tuotettua tutkimustietoa toivotaan hyödynnettävän sote-tietojärjestelmiä uudistettaessa ja kehitettäessä asiakaslähtöisemmiksi. Vaikuttavuuden lisäämiseksi pyritään käymään vielä kevään 2017 aikana neuvotteluja Tekesin sekä STM:n kanssa.

Oleellista on viedä testattu prototyyppi edelleen vuoropuheluun menossa olevien kansallisten tietojärjestelmien kehittämishankkeiden kanssa ja tutkia, miten ne haastavat prototyyppiä ja sen edelleen kehittämistä sekä miten prototyyppi haastaa niitä.

\section{Kiitokset}

MORFEUS-hanke on saanut rahoitusta Tekesin Innovaatiot sosiaali- ja terveyspalveluissa -ohjelmasta. Prototyypin rakentamis- ja testaustyössä ovat olleet vastuullisina toimijoina Lauri Majuri ja Roni Nukarinen Laureaammattikorkeakoulusta, mistä koko MORFEUShankkeen tutkijatiimi osoittaa heille parhaat kiitokset.

\section{Lähteet}

[1] Meristö T, Kantola T. Worry Management - a FutureOriented Management Innovation of Wellbeing Services. In: Bitran I, Conn S, Huizingh KRE, Kokshagina O, Torkkeli M. The Proceedings of the ISPIM Innovation Summit 2016: Moving the Innovation Horizon Conference held in Kuala Lumpur, Malaysia on 4 December to 7 December 2016. ISBN 978-952-265-931-6.

[2] Meristö T, Kantola T, Lankinen-Lifländer M. Smart Tools and Service Opportunities for Child Protection Ecosystem in the Future. Case Family View. In: RussoSpena T, Mele C (Eds.). The RESER European Association for Research on Services Proceedings. What's ahead in 
service research? New perspectives in business and society. 26th Annual RESER Conference 2016 in Naples, Italy, 8-10 September 2016. Pp. 939-953. ISBN 979-12200-1384-0.

Saatavilla. http://www.reser2016.com/proceedings---outcomes1.html

[3] Nurminen M, Meristö T. (toim.) OmaHyvinvointihanke. Väliraportti I - Pärjäin kansalaisen käyttöön? Turku; 2009. [Viitattu: 30.1.2017] Saatavilla: https://drive.google.com/file/d/0B56sGmSwrHiuZUFNO DFTZWlyWnc/view

[4] Muukkonen P, Nurminen M, Meristö T, Tuohimaa H. Pärjäin. OmaHyvinvointi-hankkeen loppuraportti. Turku; 2010. [Viitattu 30.1.2017] Saatavilla: https://drive.google.com/file/d/0B56sGmSwrHiuRmhiY zl3RHhYMkU/view

[5] Tuohimaa H, Meristö T. Pärjäin-skenaariot. Tulevaisuustarkastelu kansalaisen hyvinvoinnin apuvälineen konseptoinnissa. Turku; 2010. [Viitattu 30.1.2017] Saatavilla:

https://drive.google.com/file/d/0B56sGmSwrHiuNTV1L TIHNWJDNGc/view

[6] Korhonen M. Yhteentoimivat sote-tietojärjestelmät mahdollistavat toiminnan uudistamisen. [Internet] Alueuudistus.fi-sivusto; 17.3.2016. [Viitattu 30.1.2017] Saatavilla: http://alueuudistus.fi/blogi//blogs/yhteentoimivat-

sote-tietojarjestelmat-mahdollistavat-toiminnanuudistamisen

[7] Palveluväylä. [Internet] Valtiovarainministeriö; 2015. [Viitattu 30.1.2017] Saatavilla: http://vm.fi/palveluvayla

[8] Palvelunäkymät. [Internet] Valtiovarainministeriö; 2016. [Viitattu 30.1.2017] Saatavilla: http://vm.fi/palvelunakymat

[9] Sote-solmut selville, rahavirrat näkyviksi. [Internet] Sitra; 2015. [Viitattu 30.1.2017] Saatavilla: http://www.sitra.fi/tapahtumat/sote-palveluidenrahoitus/sote-solmut-selville-rahavirrat-nakyviksi

[10] MORFEUS-hanke. [Internet] Laureaammattikorkeakoulu ja Aalto-yliopisto; 2015. [Viitattu 30.1.2017] Saatavilla: http://morfeus.fi/
[11] Kanta, Kansallinen terveysarkisto. [Internet, viitattu 30.1.2017] Saatavilla: http://www.kanta.fi

[12] Sosiaalihuollon Kanta-palvelut [Internet] Terveyden ja hyvinvoinnin laitos (THL); 2016. [Viitattu 1.4.2017]. Saatavilla: https://www.thl.fi/fi/web/tiedonhallintasosiaali-ja-

terveysalalla/tietojarjestelmapalvelut/sosiaalihuollontiedonhallinta/sosiaalihuollon-kanta-palvelut

[13] THL. Huolen vyöhykkeistö ja huolen puheeksiottaminen. [Internet] Terveyden ja hyvinvoinnin laitos (THL). [Viitattu 30.1.2017] Saatavilla: https://www.thl.fi/fi/web/lastensuojelun-

kasikirja/tyomenetelmat-ja-

valineet/tyomenetelmat/huolen-vyohykkeisto-jahuolen-puheeksiottaminen

[14] THL. Palveluohjaus. [Internet] Terveyden ja hyvinvoinnin laitos (THL); 2015. [Viitattu 30.1.2017] Saatavilla: https://www.thl.fi/fi/web/vammaispalvelujenkasikirja/palvelujen-jarjestamisprosessi/palveluohjaus

[15] Virkkunen H, Mäkelä-Bengs P, Vuokko R. (Toim.). Terveydenhuollon rakenteisen kirjaamisen opas. Osa 1. Keskeisten kertomusrakenteiden kirjaaminen sähköiseen potilaskertomukseen. Terveyden ja hyvinvoinnin $\begin{array}{llll}\text { laitos } & \text { (THL); } & 2015 . & \text { Saatavilla: }\end{array}$ https://www.julkari.fi/bitstream/handle/10024/126020 /URN_ISBN_978-952-302-479-3.pdf?sequence=1

[16] Hoitotyön rakenteinen kirjaaminen. [Internet] Suomen lähi- ja perushoitajaliitto SuPer. [Viitattu 31.1.2017] Saatavilla: https://www.superliitto.fi/tyoelamassa/ammatissatoimiminen/osaamisen-varmistaminen/hoitotyonrakenteinen-kirjaaminen/ 